\title{
Properties of Some Minerals and Implications on Cancer
}

\author{
Bazı Minerallerin Özellikleri ve Kanser Üzerindeki Etkileri
}

\author{
Aylar Kargar' ${ }^{1}$ Mendane Saka ${ }^{2}$
}

Geliş tarihi/Received: 04.08.2020 • Kabul tarihi/Accepted: 26.04.2021

\begin{abstract}
Cancer is one of the non-communicable diseases which has more than 100 types. Although cancer mechanism is unclear, in general, it is related to oxidation-reduction reactions. Minerals based on their effects on these pathways, have different influences on cancer condition. Based on the source of calcium and the location of cancer, the results could be varied. Zinc is a mineral which participates in healing the wounds and improves the immune system. Thus, serum levels of zinc could be a predictor of cancer. Selenium has a dose-response relation with different types of cancer and shows the antioxidant roles. However, this element could worsen the patient's status. Iron creates free radicals in the body however iron deficiency anemia decreases the quality of life and affects the treatment in patients. Copper can cause damages via reactive oxygen species (ROS). In conclusion, the recommendations should be discreetly done, considering individuals' status.
\end{abstract}

Keywords: Cancer, minerals

\section{ÖZET}

Kanser 100'den fazla türü olan bulaşıcı olmayan hastalıklardan biridir. Kanser mekanizması bilinmese de, genel olarak, oksidasyon-redüksiyon reaksiyonları ile ilgilidir. Bu yolaklar üzerindeki etkilerine bağlı olarak mineraller, kanser durumu üzerinde farklı etkilere sahiptir. Kalsiyumun kaynağına ve kanserin yerine bağlı olarak, sonuçlar değişebilmektedir. Çinko, yaraların iyileştirmesinde katkıda bulunan ve bağışıklık sistemini güçlendiren bir mineraldir. Bu nedenle, serum çinko seviyeleri kanser belirteci olabilir. Selenyumun farklı kanser türleriyle doz-cevap ilişkisi vardır. Selenyum antioksidan rolü gösterir. Ancak, bu element hastanın durumunu kötüleştirebilmektedir. Demir vücutta serbest radikaller oluşturur, ama demir eksikliği anemisi yaşam kalitesini düşürür ve hastalardaki tedaviyi etkiler. Bakır, reaktif oksijen türleri (ROS) yoluyla hasarlara neden olabilir. Sonuç olarak, öneriler bireylerin durumlarına göre dikkatli bir şekilde yapılmalıdır.

Anahtar kelimeler: Kanser, mineraller

1. İletişim/Correspondence: Department of Nutrition and Dietetics, Başkent University, Ankara, Turkey

E-posta: aylar.kargar@gmail.com • ๑ https://orcid.org/0000-0001-8020-8095

2. Department of Nutrition and Dietetics, Başkent University, Ankara, Turkey (ㄱ) https://orcid.org/0000-0002-5516-426X 


\section{INTRODUCTION}

Cancer is responsible for millions of deaths each year and is affected by many factors such as diet, genetics or environmental risks. As there is not a special location for cancer, these cells can thrive in any part of the body. Lung, liver, colorectal, stomach and breast cancers are the leading cancers with high mortality respectively, in 2015, as reported by World Health Organization (WHO) (1).

On the other hand, some cancer patients have increased desire to take vitamin and mineral supplements which they believe would improve the tolerance of treatment, enhance the immune system, or even reverse the progression of the disease. However, others prefer these products as an approach to make up the probable pre-diagnosis of nutritional deficiencies brought by poor diets and lifestyle choices. Due to Rock et al. (2) standard multivitamin and mineral supplement (not exceeding $100 \%$ dietary reference intake (DRIs) is considered to be safe for individuals with eating difficulties or treatment-related side effects. However, as per the American Institute for Cancer Research (AICR) highdose dietary supplementation can stimulate cancer including cancer survivors. Furthermore, oncology practitioners request not to take dietary supplements during treatment mostly the ones with antioxidant effects such as vitamins A, C, E, beta-carotene, zinc, selenium, coenzyme Q10, and green tea extract (3).

In this review, we will try referring to some of these minerals and their possible effects on cancer.

\section{MINERALS AND CANCER}

\section{Calcium}

Even though most of the calcium is stored in the skeleton (near 99\%), rest of it also has significant physiologic functions. Calcium ions act as regulators in many systems such as nervous system, contractions of muscles and bone metabolism. Hyperactive reflexes, seizures, tetany, lethargy, muscle weakness, numbness or tingling, and confusion are among the symptoms of hypocalcemia. On the other hand, hypercalcemia is characterized by nausea, vomiting, muscle weakness, lethargy, and depression. Cancers with bone metastases or hyperparathyroidism are the common causes for hypercalcemia (3).

Relation between calcium intakes (from supplements and/or dairy products) and different cancers have been suggested in several studies. In a meta-analysis performed by Rahmati et al. (4) a strong relationship was demonstrated between total calcium intake and increased total prostate cancer. Chan et al. (5) investigated the possible impacts of calcium intakes from dairy products on prostate cancer among male physicians of the US. They supported the assumption that high intakes of dairy products (>2.50 servings/ day) could increase the risk of prostate cancer. These findings were supported by other studies assessing the effect of calcium intakes both from dairy and nondairy sources. Although these findings are debatable, the high risk of cancer seems to be related to the consumption of dairy products. This could be explained by possible influences on down-regulation of vitamin D concentrations, concentrations of insulinlike growth factor I (IGF-1) or even interactions with constituents of these products (6).

Moreover, there are other studies focusing on calcium intakes and different gastrointestinal cancers. According to Wulaningsih et al. (7) dietary intakes of calcium could affect gastrointestinal malignancy. Activation of CaSR (calcium-sensing receptor) or binding of bile acids in the gastrointestinal tract could be considered as possible effects. Furthermore, they demonstrated an imaginable double role for calcium in relation to cancer; stimulating differentiation and apoptosis of normal cells as well as tumor-promoting in carcinogenesis.

Unlike previous researches, there are also studies which claim the protective role of calcium in the body. Another presumed role of calcium is its binding ability to both fatty acids and bile. This probable pathway could prevent the damages to gastrointestinal (GI) 
tract. Studies have shown that the higher intakes of calcium especially after diagnosis lowers the risk of mortality in patients with colorectal cancer (8). Apart from these, dairy foods which are the main sources of calcium, also contains other potential anticarcinogenic participants such as vitamin $\mathrm{D}$, and conjugated linoleic acid. These nutrients could diminish the risk of total cancer by reducing the damage to GI tract (9).

Although there is some evidence in support of the theory that calcium intakes could be connected with high risks of breast cancer, calcium has the efficiency on cell-structure differentiation regulation, proliferation, and apoptosis, as well. It's alleged that one of the protective approaches of calcium could be via its direct effect on DNA repair capacity (DRC) (10). Then again, it was shown in some studies that over expression of certain calcium channels and pumps could be useful pharmacological tool due to their role in cancer therapies and many of these studies declare calcium channels, pumps and exchangers as an alternative treatments (11).

Additionally, individuals suffering from bone metastases may expose to hypocalcemia. This condition should not be treated by dietary supplements and antacids. As the consumption of calcium-containing foods has little effect on the overall management of hypercalcemia in patients, restricting the intake of these foods is not indicated in studies (3).

\section{Zinc}

As an essential mineral, zinc is found in a vast variety of enzymes and participates in many biological functions and process. Being related to functions such as supporting the immunity system, playing a role in antioxidant system, healing of wounds and improving taste makes the existence of this mineral significant for cancer patients as well as the disease itself. Therefore, in the absence of this mineral, growth retardation, poor appetite, and dysfunctions of enzymes and several immune-associated cytokines will be inevitable. Other consequences of zinc deficiency are lymphoid tissues atrophy, diminishing in $\mathrm{T}$ cells proliferation and production of cytokines mainly IL-2, IL-6, and TNF-a. Therefore, consuming zinc supplementation will be considered as an approach to enrich immune rebuilding $(3,12,13)$.

Another advantage of zinc against cancer is its roles in antioxidant systems especially superoxide dismutase. Also, via protective effects against DNA damage and gene mutation, zinc reduces the risk of cancer. Long lasting inflammations are associated with possible irrigative oxidative stress. This fact becomes more significant in patients with oral cancerous and precancerous lesions. Zinc deficiency or inadequacy can cause impairments in quenching free radicals and constructing metallothioneins. Thus, zinc serum levels can be crucial in occurrence or intensification of malignant oral lesions. Similar results were confirmed in patients with esophageal squamous cell carcinoma. Stressing on the importance of this mineral in immune functions and proliferation, apoptosis and signaling cells, principally T-cells and cytokines $(14,15)$.

Apart from previous results, Singh et al. (16) demonstrated the importance of zinc among individuals with prostate cancer. For many participants, zinc depletion itself is a significant and distinctive converting signal of healthy prostates to malignant ones. Zinc supplementations and other zinc bioavailability by enhancing compounds in diets could be beneficial for individuals suffering from prostate cancer.

On the other hand, this information should not mislead individuals to over consume zinc supplements or use it as an alternative instead of natural food sources. Du et al. (17) illustrated a possible higher supplemental intake of zinc and cancer. Due to their information, nearly half of the cancer survivors used dietary supplements without consulting their health care providers.

\section{Selenium}

Selenium concentration in the soil is one of the key factors affecting the selenium intake; causing a vast variation of the dietary intake as low as $10 \mathrm{mg} /$ day in 
areas in China to as high as $350 \mathrm{mg} /$ day in countries such as Venezuela (18) Due to this nutrient's role as cofactor in various antioxidants, it is considered to have preventive effects against cancer (19).

Cancer cells create more ROS than normal ones. In addition, cancer cell being hypoxic, produce lactic acid in cytosol instead of pyruvate oxidation in mitochondria, stated as Warburg effect. All these together make cancer cells more vulnerable to oxidative stress and target the antioxidant capacity of cancer cells. On the other hand, selenium found as a part of selenoproteins possess significant antioxidant property. The significance of this element against oxidative stress is because of direct effect of selenoproteins as antioxidants and indirectly on the activation and regeneration of constituents such as vitamin C and E, and Q10 (Coenzyme 10) (20).

Selenium's role on cancer have two opposite aspects. Many studies have suggested a U-shaped dose-response relation between selenium intake and cancer. While selenium intakes diminish DNA damages in prostate tissue, extreme consumption of this element could cause oxidative damage and enhance DNA damage due to studies over animal models (15).

Same results were confirmed in other studies conducted on cancer patients. In the study of Kristal et al (21), the effect of selenium with and without vitamin $\mathrm{E}$ on prostate cancer patients with different serum levels of selenium was evaluated. Based on the results of this research, selenium supplementation were neither a threat nor an advantage among individuals with low selenium levels. On the other hand, this supplementation intensified the risk of high-grade cancer among men with high selenium levels. Moreover, the risk of cancer increased with vitamin E intakes among patients with low selenium levels.

Many studies have investigated the possible doseresponse relation between selenium intake and cancer. In a prospective cohort study, individuals primarily diagnosed with non-metastatic prostate cancer were followed for more than twenty years. Selenium intakes of these patients were classified into four groups. The results indicated a possible U-shaped relation claiming the adverse effects of very high intakes of selenium. In addition, it was suggested that selenium supplementation in high doses could increase the risk of prostate cancer mortality (22).

\section{Iron}

As a crucial mineral for many vital processes in the body such as cell replication, metabolism, and growth, iron has enzymatic roles which signify this element's contribution in reactions related to free radicals. Iron can produce oxidative stress prompting substances (e.g.,hydroxyl radicalsandhydrogen peroxide)through Fenton-Type and Haber-Weiss reactions. Chronic imbalances in productions and gathering these free radicals are allied with malignancies. Furthermore, in most malignancies, iron homeostasis deteriorates in many ways predominantly in expressions of proteins that are iron dependent $(23,24)$.

One of the most common complications of cancer is anemia which displays in the forms of absolute or functional iron deficiencies. Hemolysis, bleeding (acute/chronic), vitamin B9 and B12 deficiencies or chemo- / radiotherapy related factors can cause or deteriorate iron deficiency in cancer patients. In addition, iron absorption and loss through excretion is increased in these patients. All these together weaken the individuals' quality of life and their daily performances. On the other hand, cancer cells need more iron for their rapid growth and proliferation. Due to this theory, cancer cells are more dependent and sensitive to iron deficiencies. Studies have demonstrated that neoplastic cells become resistant to therapies in the presence of increased levels of iron; iron chelators could be an approach in anti-tumor treatments as well $(24,25)$.

Serum level of ferritin, also known as iron storage protein, could rise in physiological situations such as infections, inflammation or in chronic diseases. Therefore, ferritin's enzymatic role in respiratory 
pathways, increased values of serum ferritin, could have carcinogenic consequences because of free radicals' production (14).

Moreover, one of the common consequences in cancer patients is systemic iron dysregulation. In some cancer types, such as lung cancer, raised levels of interleukin 6 upregulated hepcidin is noted, which leads to cancer-related anemia and intracellular iron accumulation (26).

\section{Copper}

Over the past years many studies have been focusing on investigating the probable role of copper in both the etiology and growth of tumors. Based on several studies, higher levels of serum $\mathrm{Cu}$ was linked with particular types of cancers (e.g. breast, lung, and liver). Conversely, $\mathrm{Cu}$ is one of the elements widely distributed in biological tissues, contributing in formatting of numerous proteins and enzymes and transport of oxygen (27).

Copper is transported in blood in the $\mathrm{Cu}$ (II) form. Like iron copper is an important cofactor in reductionoxidation reactions (redox). These reactions consist of all chemical process related to the transfer of electrons and oxidation in cells. This element has the ability to beget oxidative damages by producing reactive oxygen species (ROS). Free radicals are one of the principal factors in peroxidation of lipids, oxidation of proteins, and destruction of nucleic acids in cells. And, this illustrates the importance of increased levels of serum copper to improve cancers such as oral cancer $(14,28-30)$.

Carried as serum proteins (e.g. ceruloplasmin or albumin) copper as $\mathrm{Cu}$ (II), should be converted to $\mathrm{Cu}$ (I) via the cell surface metallo-reductases before entering any target cell. Inside the cells, they bind to cytoplasmic carriers known as metallo-chaperones. High concentrations of copper inside the cells can be toxic as well. Many cancer types reveal high amounts of intra-cellular copper. Moreover, accumulated copper disturbs the balance of other trace elements e.g. zinc, selenium, and copper status and increases the $\mathrm{Cu} / \mathrm{Zn}$ and $\mathrm{Cu} / \mathrm{Se}$ ratio and studies have shown the relation between the high ratio of $\mathrm{Cu} / \mathrm{Zn}$ and $\mathrm{Cu} / \mathrm{Se}$ with a variety of cancers such as lung, breast, prostate, bladder, esophageal, colorectal, and hepatocellular carcinoma. Therefore, copper is considered to be a limiting element and factor through progression, growth, and metastasis processes and most importantly, benefits of copper chelators with/or without other therapies in patients have been demonstrated in studies (29-31).

\section{MINERALS, CACHEXIA AND CHEMOTHERAPY}

Incidence of cachexia is high in cancer patients and seems to be inevitable in individuals with advanced cancer stages. Cachexia is considered as a multi-factorial syndrome, includes systematic inflammations, an imbalance of energy status, negative protein balance, continuous loss of lean body mass (sometimes with loss of fat mass) and general weakness. These complications are combined by abnormalities in fluid and related micro-nutrients, in patients $(3,32,33)$.

In most cancer cells rate of lipolysis is high and accounts mainly for the loss of adipose tissue as compared to decreased lipogenesis. Moreover, increased LMF (lipid-mobilizing factor) and PIF (proteolysis-inducing factor) levels have also been demonstrated in studies. $(32,33)$.

Quality of life (QL) is one of the recent terms with high significance with respect to cancer patients. WHO describes it as "an individual's perception of their position in life in the context of the culture and value systems in which they live and in relation to their goals, expectations, standards, and concerns". This parameter can be considered as a tool for measuring the difference between patients' current status and expectations. Cachexia has effects both on QL and the responses of individuals to chemotherapy. Thus, medical therapies should be accompanied by approaches enhancing the QL such as modified diets and/or exercise (33-35).

Additionally, one of the most common side effects of chemotherapy is the loss of taste and smell which 
leads to decreased appetite, reduced dietary intake of patients and overall QL. Studies have shown that multiple antioxidant supplements could be beneficial in patients with such deficiencies. Supplements containing minerals such as zinc and selenium in individuals with poor nutritional status alleviate these side effects and improve patients' immunity system $(36,37)$.

Moreover, some studies indicate possible indirect effects of vitamin D on cancer cachexia. Vitamin D intakes (up to 600-800 international units) in patients suffering from cancer (especially those at risk for poor nutritional status) could be beneficial in order to avoid muscle wasting. This could lead to elude weight loss and muscle mass decreases among individuals, as well as diminished functional capacity, increased hospitalization and obstacle rate, as well as mortality in cancer patients $(38,39)$.

Additionally, Molanouri Shamsi, et al (40) showed that selenium nanoparticles caused enhanced cachexia symptoms in mice with breast cancer. Furthermore, selenium has an antioxidant role which reduces tumor volume in tumor-bearing mice. Besides, interval aerobic training has synergic effect with selenium nanoparticles on preventing cachexia and decreasing tumor volume.

However, the American Institute for Cancer Research, American Cancer Society, and ESPEN due to the side effects of cancer therapy, restricted diets and cachexia existence in many patients suggest multivitamin/ multimineral supplements (dose in the recommended dietary allowance range and avoid consuming high doses) (39).

\section{CONCLUSIONS}

In summary, the exact effect of minerals remains controversial refrains oncologists from recommending antioxidants containing dietary supplements (such as Zn and Se) for cancer survivors especially individuals receiving therapy. Cancer patients or former cancer patients groups are extremely sensitive against multivitamin and minerals (MVM) supplementation. Consumption of minerals should be avoided in order to prevent deterioration or recurrence of the disease. On the other hand, beneficial influences of mineral supplementation were demonstrated among individuals with deficiencies or insufficient intakes (3). In general, it may be concluded that healthy diet and lifestyle have significant importance in an individuals' nutritional status. On the other hand, cancer mechanism has not been understood clearly, therefore, more studies are needed to determine the precise effects of minerals on cancer.

Conflict of interest: The authors declare that they have no conflict of interest.

\section{KAYNAKLAR}

1. WHO Media Centre. Fact sheets. Detail. Cancer. World Health Organization. 2017. Available from: https://www. who.int/news-room/fact-sheets/detail/cancer. Accessed June 82020.

2. Rock CL, Doyle C, Demark-Wahnefried W, Meyerhardt J, Courneya KS, Schwartz AL, et al. Nutrition and physical activity guidelines for cancer survivors. CA Cancer J Clin. 2012;62(4):243-74.

3. Mahan LK, Raymond JL. Krause's Food \& Nutrition Care Process. 14th Edition. St. Louis, Missouri: ELSEVIER; 2016. p. 729-756.

4. Rahmati S, Azami M, Delpisheh A, Hafezi Ahmadi MR, Sayehmiri K. Total calcium (dietary and supplementary) intake and prostate cancer: a systematic review and meta-analysis. Asian Pac J Cancer Prev. 2018;19(6):144956.

5. Chan JM, Stampfer MJ, Ma J, Gann PH, Gaziano JM, Giovannucci EL. Dairy products, calcium, and prostate risk in the Physicians' Health Study. Am J Clin Nutr. 2001;74(4):549-54.

6. Aune D, Navarro Rosenblatt DA, Chan DSM, Vieira AR, Vieira R, Greenwood DC, et al. Dairy products, calcium, and prostate cancer risk: a systematic review and metaanalysis of cohort studies. Am J Clin Nutr. 2015;101:87117.

7. Wulaningsih W, Michaelsson K, Garmo H, Hammar N, Jungner I, Walldius G, et al. Serum calcium and risk of gastrointestinal cancer in the Swedish AMORIS study. BMC Public Health. 2013;13:663.

8. Yang B, McCullough ML, Gapstur SM, Jacobs EJ, Bostick RM, Fedirko V, et al. Calcium, vitamin D, dairy products, and mortality among colorectal cancer survivors: The 
Cancer Prevention Study-II Nutrition Cohort. J Clin Oncol. 2014;32:2335-43.

9. Park Y, Leitzmann MF, Subar AF, Hollenbeck A, Schatzkin A. Dairy food, calcium, and risk of cancer in the NIH-AARP Diet and Health Study. Arch Intern Med. 2009;169(4):391-401.

10. Vergne Y, Matta J, Morales L, Vargas W, Alvarez-Garriga C, Bayona M. Breast cancer and DNA repair capacity: Association with use of multivitamin and calcium supplements. Integr Med (Encinitas). 2013;12(3):38-46.

11. Bong AHL Monteith GR. Calcium signaling and the therapeutic targeting of cancer cells. BBA - Molecular Cell Research. 2018;1865:1786-94.

12. Meksawan K, Sermsri U, Chanvorachote P. Zinc supplementation lmproves anticancer activity of monocytes in type- 2 diabetic patients with metabolic syndrome. Anticancer Research. 2014;34:295-300.

13. Sangthawanz D, Phungrassamia T, Sinkitjarurnchai W. Effects of zinc sulfate supplementation on cell mediated immune response in head and neck cancer patients treated with radiation therapy. Nutrition and Cancer 2015;67(3):449-56.

14. Baharvand M, Manifar S, Akkafan R, Mortazavi H, Sabour S. Serum levels of ferritin, copper, and zinc in patients with oral cancer. Biomed J. 2014;37:331-6.

15. Hashemian M, Poustchi H, Abnet CC, Boffetta P, Dawsey SM, Brennan PJ, et al. Dietary intake of minerals and risk of esophageal squamous cell carcinoma: results from the Golestan Cohort Study. Am J Clin Nutr. 2015;102:102-8.

16. Singh CK, Pitschmann A, Ahmad N. Resveratrol-zinc combination for prostate cancer management. Cell Cycle. 2014;13(12):1867-74.

17. Du M, Luo H, Blumberg JB, Rogers G, Chen F, Ruan $\mathrm{M}$, et al. Dietary supplement use among adult cancer survivors in the United States. J Nutr. 2020;150(6):14991508.

18. Retondario A, de Moura Souza A, Fernandes R, Bricarello LP, de Almeida Alves M, Ramos Zeni LAZ, et al. Usual intake and dietary sources of selenium in adolescents: A cross-sectional school-based study. Clin Nutr ESPEN. 2019;33:91-7.

19. Narod SA, Huzarski T, Jakubowska A, Gronwald J, Cybulski C, Oszurek O, et al. Serum selenium level and cancer risk: a nested case-control study. Hered Cancer in Clin Pract. 2019;17:33.

20. Fernandes AP, Gandin V. Selenium compounds as therapeutic agents in cancer. Biochim Biophys Acta. 2014;1850(8):1642-60.

21. Kristal AR, Darke AK, Morris JS, Tangen CM, Goodman PJ, Thompson IM, et al. Baseline selenium status and effects of selenium and vitamin E supplementation on prostate cancer risk. JNCI (J Natl Cancer Inst) [Internet].
2014 Mar [cited 2020 Jan 24];106(3):djt456. Available from: https://pubmed.ncbi.nlm.nih.gov/24563519/

22. Kenfeld SA, Van Blarigan EL, DuPre N, Stampfer MJ, Giovannucci EL, Chan JM. Selenium supplementation and prostate cancer mortality. J Natl Cancer Inst. 2014;107(1):360.

23. Torti SV, Torti FM. Iron and cancer: more ore to be mined. Nat Rev Cancer. 2013;13(5):342-55.

24. Marques O, da Silva BM,Porto G,Lopes C.Iron homeostasis in breast cancer. Cancer Lett. 2014;28;347(1):1-14.

25. Ludwig H, Evstatiev R, Kornek G,AAapro M, Bauernhofer $\mathrm{T}$, Buxhofer-Ausch V, et al. Iron metabolism and iron supplementation in cancer patients. Wien Klin Wochenschr. 2015;127:907-919.

26. Kuang Y, Wang Q. Iron and lung cancer. Cancer Lett. 2019;464;56-61.

27. Li H, Wang J, Wu C, Wang L, Chen ZS, Cui W. The combination of disulfiram and copper for cancer treatment. Drug Disov Today. 2020;25(6):1099-108.

28. Adeoti ML, Oguntola AS, Akanni EO, Agodirin OS, Oyeyemi GM. Trace elements; copper, zinc and selenium, in breast cancer afflicted female patients in LAUTECH Osogbo, Nigeria. Indian J Cancer. 2015;52(1):106-9.

29. Safi R, Nelson ER, Chitneni SK, Franz KJ, George DJ, Zalutsky MR, McDonnell DP. Copper signaling axis as a target for prostate cancer therapeutics. Cancer Res. 2014;74(20):5819-31.

30. Denoyer D, Masaldan S, La Fontaine S, Cater MA. Targeting copper in cancer therapy: 'Copper that Cancer'. Mettallomics. 2015;7(11):1459-76.

31. Mao S, Huang S. Zinc and copper levels in bladder cancer: a systematic review and meta-analysis. Biol Trace Elem Res. 2013;153(1-3):5-10.

32. Mochamat, Cuhls H, Marinova M, Kaasa S, Stieber C, Conrad R, et al. A systematic review on the role of vitamins, minerals, proteins, and other supplements for the treatment of cachexia in cancer: a European Palliative Care Research Centre cachexia project. J Cachexia Sarcopenia Muscle. 2017;8(1):25-39.

33. Aoyagi T, Terracina KP, Raza A, Matsubara H, Takabe K. Cancer cachexia, mechanism and treatment. World J Gastrointest Oncol. 2015;7(4):17-29.

34. Kiagia M, Syrigos KN, Wasif Saif M. Quality of life in patients with pancreatic cancer. JOP. J Pancreas (Online). 2014;15(4):317-8.

35. Callman KC. Quality of life in cancer patients. J Med Ethics. 1984;10:124-7.

36. Lyckholm L, Heddinger SP, Parker G, Coyne PJ, Ramakrishnan V, Smith TJ, et al. A randomized, placebo controlled trial of oral zinc for chemotherapyrelated taste and smell disorders. J Pain Palliat Care Pharmacother. 2012;26(2):111-4. 
37. Gröber U, Holzhauer P, Kisters K, Holick MF, Adamietz IA. Micronutrients in oncological intervention. Nutrients. 2016;8(3):163.

38. Ravasco P. Nutrition in cancer patients. J Clin Med. 2019;8:1211.

39. Prado CM, Purcell SA, Laviano A. Nutrition interventions to treat low muscle mass in cancer. Journal of Cachexia,
Sarcopenia and Muscle. 2020;11:366-80.

40. Molanouri Shamsi M, Chekachak S, Soudi S, Quinn LS, Ranjbar K, Chenari J, et al. Combined effect of aerobic interval training and selenium nanoparticles on expression of IL-15 and IL-10/TNF-alpha ratio in skeletal muscle of 4T1 breast cancer mice with cachexia. Cytokine. 2017;90:100-8. 